\title{
Research on the Investment Decision of Enterprise Marketing
}

\author{
Biao Wang \\ School of Resources and Materials, Northeastern University, \\ Qinhuangdao Branch, \\ Qinhuangdao, China \\ Email:wangbiao320@163.com
}

\author{
Chunxiang $\mathrm{Wu}$ \\ Vocational and technical college of Qinhuangdao \\ Email:wuchx80@126.com
}

Rong Wang

Vocational and technical college of Qinhuangdao

\begin{abstract}
If enterprises want to keep good benefit in the increasingly competitive circumstance, the best way is effective marketing. Thus, the scientific marketing strategy is particular important. In this paper, through the establishment of marketing decision model and simulation, enterprise can find each period market share, profit growth and the current profit. According to it, enterprises will make rational investment decision.
\end{abstract} growth

Keywords-Marketing investment; market share; profit

\section{INTRODUCTION}

With the globalization of the market and customer needs changing, the marketing is increasingly important in the development of enterprise. Each enterprise is very concerned about the relationship of the marketing and market share as well as the relationship of marketing and profit. Through the illustration of this text, you will find the relationship between them. According to the conclusion, you can make reasonable marketing decision.

\section{MODELLING}

This paper introduces an effective marketing investment $\mathrm{W}$, which is the amount of marketing investment played a role to market share in a period. The Model can be summarized as:

AdjustedMarketshare $=$ LowerLimit + RrtentionRatio $\times$

$(\operatorname{Pr}$ eviousMarketShare - LowerLimit $)+(a-b) \frac{W^{c}}{d+W^{c}}$

$W=$ mediaefficiecy $\times$ effectivea dverti $\sin$ gcopy

$\times$ adverti $\sin$ ginvestment

In the assessing marketing effectiveness, there are several factors effect, which play the key role is the media efficiency index and marketing effectiveness indicators. So there introduce two important indicators.

By this model, can get the following two models:
A. Brand sales

$$
\begin{aligned}
\text { Adjustedsales }= & \text { produtscategorysale } \sin \text { dex } \\
& \times \text { adjustedmarketshare }
\end{aligned}
$$

B. Profit

MPC = nitsalescontribution

$\times$ brandsales $\times$ marketinginginvestment

The model advantage:

First, the marketing expenditure of the model is really effect on sales.

Secondly, enterprises can more clearly see which part of the marketing investment plays role in sales growth.

Finally, a subtle change in the marketing operation can cause how many sales and market share change.

\section{Simulation}

\section{A. BACKGROUND:}

A domestic beverage company in the nineties golden era, the market share in several regions had reached to $15 \%$. In the late 21th century, the beverage market presents: the strengthening of the monopoly, competing mainly on price. In this market environment, the several major beverage companies control the $3 / 4$ of the domestic market. The company market share reduces from $12 \%$ in early 90 s to the current $5.5 \%$.

In 2011, the company began to focus on the role of marketing. Company decided to increase marketing budget by $20 \%$ each quarter from the July 1 st, 2011 to the June 30th, 2011 end.

Based on the above analysis, we can get the initial data (table I, table II) 
TABLE I. BASIC DATA

\begin{tabular}{|l|l|}
\hline Beginning of market share $(\%)$ & 5.94 \\
\hline Initial marketing investment (million) & 2.20 \\
\hline $\begin{array}{l}\text { If marketing reaches saturation level can be realized in the end of the } \\
\text { market share (\%) }\end{array}$ & 6.93 \\
\hline Adding to 20\% marketing investment (million) & 2.64 \\
\hline If the ads increased by 20\% can be realized the market share in the end (\%) & 6.27 \\
\hline If not advertise, can be realized the market share in the end (\%) & 5.17 \\
\hline Do not advertise, long-term market share (\%) & 0 \\
\hline Brand Price (yuan) & 18.92 \\
\hline Profit contribution (yuan / piece) & 4.95 \\
\hline Average price (yuan) & 18.92 \\
\hline Each period product sales (million boxes) & 24.2 \\
\hline Each period product sales growth rate (\%) & 1.1 \\
\hline
\end{tabular}

TABLE II. MEDIA EFFICIENCY AND AD COPY EFFICIENT INDEX

\begin{tabular}{|l|c|c|}
\hline Quarter & $\begin{array}{c}\text { Media } \\
\text { efficiency }(\%)\end{array}$ & $\begin{array}{c}\text { Ad copy efficient } \\
\text { index }\end{array}$ \\
\hline The first quarter & 57.93848 & 1.45 \\
\hline The second quarter & 58.82393 & 1.50 \\
\hline The third quarter & 59.64614 & 1.55 \\
\hline The fourth quarter & 58.82393 & 1.50 \\
\hline
\end{tabular}

Explanation: Each of the parameters will be calculated by the survey data

\section{B. SOLVING}

First, the above mentioned brand sales and profit formula are set to MKENG software.
Second, take the initial data in the MKENG software.

We can obtain the enterprise market share, brand sales and profit under the enterprise marketing budget increase by $20 \%$, as shown in the table III.

TABLE III. BRAND SALES AND PRODUCT PROFIT CHANGE

\begin{tabular}{|c|c|c|c|c|c|c|}
\hline month & $\begin{array}{c}\text { Marketing } \\
\text { budget } \\
\text { (million) }\end{array}$ & $\begin{array}{c}\text { Ads copy } \\
\text { efficient index }\end{array}$ & $\begin{array}{c}\text { Media } \\
\text { efficiency }\end{array}$ & $\begin{array}{c}\text { market } \\
\text { share }\end{array}$ & $\begin{array}{c}\text { Brand sales } \\
\text { (million) }\end{array}$ & profit(million) \\
\hline Beginning & 2.20 & 1.45 & 0.58 & $5.96 \%$ & 27.3 & 475.9 \\
\hline 1 & 2.64 & 1.45 & 0.58 & $5.97 \%$ & 27.6 & 462.9 \\
\hline 2 & 2.64 & 1.45 & 0.58 & $5.98 \%$ & 28.0 & 468 \\
\hline 3 & 2.64 & 1.50 & 0.59 & $6.09 \%$ & 28.8 & 473.1 \\
\hline 4 & 2.64 & 1.50 & 0.59 & $6.18 \%$ & 29.6 & 478.3 \\
\hline 5 & 2.64 & 1.50 & 0.59 & $6.26 \%$ & 30.3 & 483.6 \\
\hline 6 & 2.64 & 1.55 & 0.60 & $6.42 \%$ & 31.4 & 488.9 \\
\hline 7 & 2.64 & & & & & \\
\hline
\end{tabular}




\begin{tabular}{|c|c|c|c|c|c|c|}
\hline month & $\begin{array}{c}\text { Marketing } \\
\text { budget } \\
\text { (million) }\end{array}$ & $\begin{array}{c}\text { Ads copy } \\
\text { efficient index }\end{array}$ & $\begin{array}{c}\text { Media } \\
\text { efficiency }\end{array}$ & $\begin{array}{c}\text { market } \\
\text { share }\end{array}$ & $\begin{array}{c}\text { Brand sales } \\
\text { (million) }\end{array}$ & profit(million) \\
\hline 8 & 2.64 & 1.55 & 0.60 & $6.56 \%$ & 32.4 & 494.5 \\
\hline 9 & 2.64 & 1.55 & 0.60 & $6.68 \%$ & 33.4 & 499.7 \\
\hline 10 & 2.64 & 1.50 & 0.59 & $6.69 \%$ & 33.8 & 505.2 \\
\hline 11 & 2.64 & 1.50 & 0.59 & $6.70 \%$ & 34.2 & 510.8 \\
\hline 12 & 2.64 & 1.50 & 0.59 & $6.72 \%$ & 34.7 & 516.4 \\
\hline
\end{tabular}

According to the above data, they can be shown as Figure 1. The bottom curve stands for each marketing budget. The largest slope curve represents the market share in different period of marketing investment. Two looks

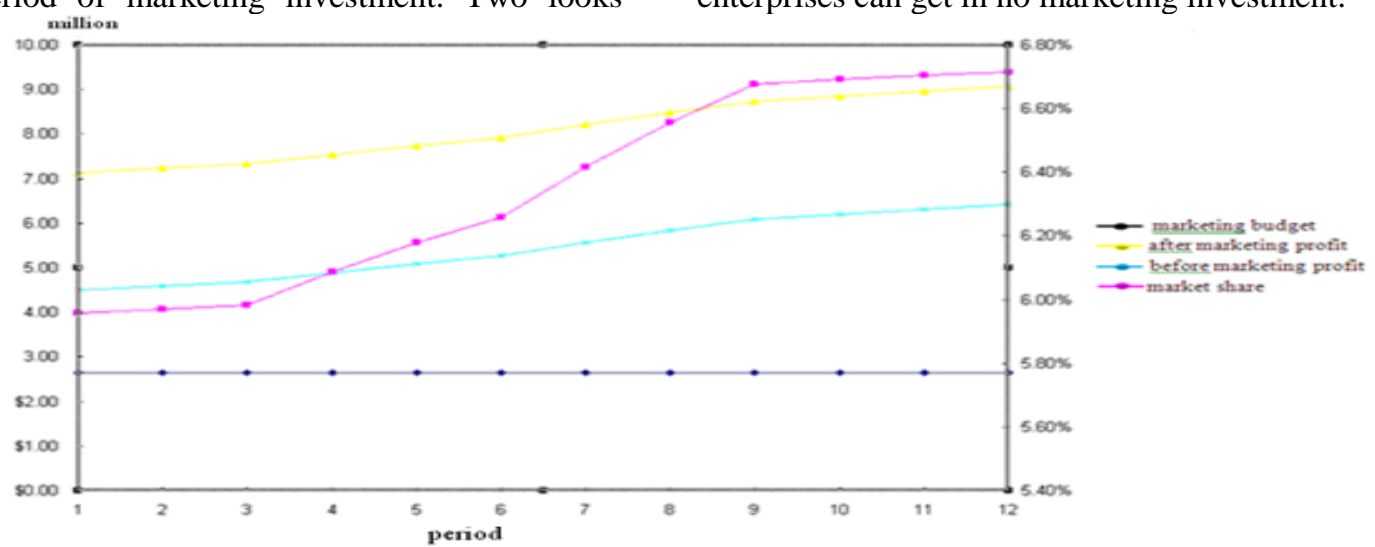

Figure 1 Marketing budgets, profit and market share tendency figure

\section{RESULTS}

From the table III and the figure 1, the following conclusions can be drawn

A. Companies in this article, the most important marketing investment is nine month, when the market share reaches the highest point. Company should keep the marketing investment at the moment.

B. Enterprises can adjust their marketing investment on the base of the relationship between marketing investment and profit situation.

C. The relationship between market share and marketing investment is not proportion function. Reaching a certain level, the marketing profit curve is flat. That means to control the marketing investment.

\section{V.PROSPECT}

Due to time constraints and mine level, this paper has some limitations. For example:

A. Only consider two factors that affect the marketing budget. If all factors are taken into account, may be more complete model.

B. This article only consider one model. In fact, there are many model of marketing strategy. parallel ( actually not parallel ) curve. The above is the profit, which enterprises can get on behalf of marketing investment. The following one is the profit, which enterprises can get in no marketing investment.
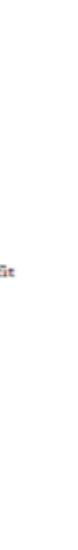